\title{
The Bank For International Settlements: An Evolutionary Institution
}

\author{
Michael P. Hughes, Francis Marion University, USA
}

Chris Palke, Francis Marion University, USA

\begin{abstract}
Established in 1930 in Basel, Switzerland, to expedite and supervise the payment of reparations by Germany to the victors of World War I, the Bank for International Settlements (BIS) quickly evolved into a banking establishment for various national central banks to negotiate and work out mutually-beneficial monetary policies and financial arrangements outside of the usual political and national channels. During World War II the BIS stayed open as a neutral central bank for central banks and provided significant back-channel communications between the Allied and Axis powers that could not have occurred any other way. As an example, discussions for the reconstruction of postWWII Germany were underway between German and Allied representatives to the BIS at least two years prior to Germany's surrender in May 1945. The post-WWII BIS then went on to become a global central bank for the world's national central banks. In spite of the BIS holding so much effective financial power on an international scale and, hence, affecting nearly everyone in the world, few have ever heard of the BIS. This includes many economists and financial-economists. Why? Although technically not a secret organization, the BIS has always maintained an intentionally low profile. The BIS has never advertised its existence. It operates through many other organizations it has either directly created or where it holds major influence. This paper discusses the BIS, its history, and its impact and influence on world events. Questions concerning the role the BIS should possibly play in world events and central banking are raised for discussion near the end of this paper.
\end{abstract}

This paper is focused primarily towards both upper-level undergraduate and graduate finance and economics courses, particularly in the areas of money, banking and financial institutions, financial markets, and monetary policy. However, other courses, to include those outside of the financial-economic arena, can find great use for this subject matter as well. Such outside arenas could include political science and history courses.

Keywords: International Finance; Banking; Central Banking; Financial Crisis; Finance

\section{INTRODUCTION}

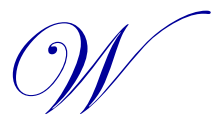

hat is the Bank for International Settlements (BIS)? In all too many cases, even when asking those among the best-educated of contemporary society this question, you will usually receive a dumbfounded expression and possibly a shrug. This is true even among many economists and financial-economists. Many know nothing of and, for that matter, have even heard of the BIS. For those few who do know something about the BIS, you usually receive rather varied opinions. Some believe it to be an essential component of international banking and global monetary policy. Others, however, feel uneasy about the BIS and maybe even voice contempt for what appears to be a secretive and exclusive club, and an unelected organization that possesses too much power over the lives of the everyday peoples of the world. Is it possible that both opinions are true, at least in part?

\section{THE BIS}

The Bank for International Settlements is a global center for financial and economic interests. While the BIS' role has evolved over time, a few key aspects have always remained the same and established the foundation for its existence. The BIS is one of the least known institutions in the global banking system. While some, who know of its existence, believe it to be a sinister organization aimed at global financial domination, others see it as a key part of the final line of defense for the world's national banking systems. Its main mission, in its own words, is "to serve central banks in their pursuit of monetary and financial stability, to foster international cooperation in these areas, and to act as a bank 
for central banks" (Lebor, 2013a). In pursuit of its primary mission, the BIS performs the following basic functions to help promote global financial stability (BIS, 2018a):

- Foster discussion and facilitate collaboration among central banks.

- Support dialogue with other authorities that are responsible for promoting financial stability.

- Carry out research and policy analysis on issues of relevance for monetary and financial stability.

- Act as a prime counterparty for central banks in their financial transactions.

- Serve as an agent or trustee in connection with international financial operations.

The BIS is not a government agency nor is it associated with any government. The BIS is not a bank that affiliates or caters to corporations or private individuals for their banking needs. Nonetheless, the BIS is a bank, it is an international financial institution, and it is a forum that facilitates the development of monetary strategy to ensure the stability of the central banks and their respective economies. The foundation of BIS is to collaborate with central banks for the benefit of central banks and the mission of global financial stability. According to Adam Lebor, a noteworthy author of several works concerning the BIS, "The BIS is a unique institution: an international organization, an extremely profitable bank, and a research institute founded, and protected, by international treaties" (Lebor, 2013a). The BIS provides financial asset management and arranges short-term credit to central banks, as needed. In order to facilitate these short-term transactions and services for central banks, the BIS engages in duties that include (BIS, 2018b):

- Purchasing, selling, opening accounts, and maintaining custody in gold, on its own behalf or the central banks' behalf.

- Loaning to or borrowing from the central banks.

- Entering into short-term obligation transactions, such as bills of exchange, promissory notes, or checks, on its own behalf or the central banks' behalf.

- Purchasing or selling negotiable securities.

- Discounting and re-discounting bills from its own portfolio or the central banks' portfolios.

- Creating and maintaining bank accounts with the central banks.

- Accepting deposits from the central banks and other parties.

- Acting an as agent or correspondent of the central banks.

- Acting as a trustee or agent in international settlement transactions.

While the BIS is often referred to as a "central bank for central banks," it is not a central bank in the true sense of what that means. Unlike a central bank, the BIS is prohibited from creating money, loaning money to governments, or acquiring significant interest in any business transaction or real estate venture. On the other hand, a concern of great importance to the BIS and central banks alike is the need for liquidity. The need for asset liquidity is based on assumable overnight loans requested from central banks which are part of their reserve assets deposited with the BIS. In accomplishing this the BIS uses its capital through direct investments with large international banks and institutions and puts the remaining items in short-term government securities, buying and selling gold, and entering into foreign exchange transactions. Currently, over 130 banking institutions use the BIS' operations. The BIS' current deposits now account for over $7.6 \%$ of the foreign exchange reserves and offer a strong reminder why liquidity is an important element in maintaining stable international markets (Felsenfeld \& Bilali, 2004).

Considering the BIS' many and useful financial functions, its main contribution to the soundness of the world's central banks is its facilitation of collaboration between its member central banks. Since its creation, the strategic and policy direction of BIS has been determined by its Board of Directors. The Board of Directors is composed of 21 members, with six ex officio members consisting of the central bank governors of Belgium, France, Germany, Italy, the United Kingdom, and the United States. These ex officio members automatically hold a seat on the board and are considered the financial powerhouses of the world (BIS, 2018c). However, the real success of BIS has purportedly been the product of its many secretive meetings and the protective banking structures developed in those meetings.

The BIS is protected from governmental and political interference by many different immunities that were established during its founding in 1930 and is a foremost reason why central banks are drawn to the institution. The BIS seeks to be a global financial stabilizing force, encouraging financial stability and international prosperity in the face of the world's ever-changing political and economic situations. 


\section{HISTORY OF THE BIS}

The fighting during World War I (WWI) ended with the signing of the armistice on November 11, 1918. Peace negotiations continued for several months after that, eventually culminating in the signing of the Treaty of Versailles on June 28, 1919. A particularly controversial condition of the treaty was the assignment of liability for damages caused by the war to Germany, for both Germany and for her allies. Germany was assessed $\$ 33$ billion in liabilities under the treaty, which were to be addressed through periodic reparation payments. This amount was twice the size of the Germany's total economy in 1925" (Bowers, 2015).

Initially Germany begrudgingly made the payments, but by the early 1920's this became increasing difficult as the nation's economic conditions began to deteriorate. Germany found recovering from devastation caused by the war insurmountable. Much of this was directly attributable to the limitations imposed by the Treaty of Versailles. In addition to the oppressive financial liabilities assessed Germany, and the associated onerous reparation payments, the treaty imposed other severe restrictions on Germany's ability to import raw materials and export products. Germany had long been, and remains today, an export nation. Its economy required, and still does, that Germany be able to import raw materials, manufacture products from those raw materials, and then export a significant amount of the finished products for sale in other nations. Inhibiting this process constrained Germany's ability to recover economically from WWI and, in turn, to generate the necessary revenue to make the reparation payments. As a result, Germany resorted to borrowing funds from other nations to keep its government functioning and to make the timely reparation payments mandated by the Treaty of Versailles. As the economic situation in Germany deteriorated, the political situation declined as well.

By 1928, as political instability and civil unrest grew in Germany, international lending began to slow. Predictably, Germany eventually slid into default on its reparation payments. As international concern grew over Germany's inability to meet its fiscal obligations, the Reparations Committee, established by the Treaty of Versailles for managing the reparation payments, began to take active measures. It became clear that Germany's mounting debt would have to be restructured to ensure stability within the international theatre and so that German reparation payments could resume. To address this situation, the Reparations Committee developed two different plans. The first was the Dawes Plan, which allowed for a reduction in reparations payment amounts. Later, the Young Plan was developed to address shortfalls in the Dawes Plan. The Young Plan was developed by Owen Young, an American industrialist and diplomat at the Second Reparations Conference in 1929. Young's plan was an adoption of the Dawes Plan, which Young had coauthored in 1924. The Young Plan took the ideas of the Dawes Plan further and suggested the creation of a settlement agency - an international or "global" bank - and payment of reparations through annuities (Felsenfeld \& Bilali, 2004). "The Young Plan contained a general description of the nature and functions of the international bank, which was set up under the Annexes to The Hague Agreements and included drafts of the bank's charter and its statues, as well as other relevant documents" (Auboin, 1955).

Dawes, also an American, and Young both had significant political and banking interests in the creation of a "global bank." (Bowers, 2015). The United States' Federal Reserve also had an interest in the creation of a "global bank." The Federal Reserve's interest was that through a "global bank" it could promote American banking structures on a global scale. Such a "global bank" could also help reconstruct and nurture a prosperous Europe, which in turn would have an increased ability to absorb American exports. The problem of German reparation payments presented an excellent opportunity, and with perfect timing, to create such an international bank. In 1930 the Young Plan was ratified at The Hague Conference and the BIS formally established. At its establishment the BIS' stated purpose was to ensure timely and continuous German reparation payments to the victorious WWI Allied nations. In short, the BIS took over the functions of the Reparations Committee created by the Treaty of Versailles. The title of the BIS, the Bank for International Settlements, comes from this original purpose.

With the establishment of the new international bank, important details still needed to be outlined such as where would BIS be located, who would provide initial capital, and what other salient aspects needed to be considered. After some deliberation Basel, Switzerland was selected as the main headquarters for BIS. According to the BIS, "the choice of Switzerland for the seat of the BIS was a compromise by those countries involved in the establishment of the BIS: Belgium, France, Germany, Italy, Japan, the United Kingdom, and the United States. When consensus could not be reached on locating the Bank in London, Brussels, or Amsterdam, the choice fell on Switzerland. As an independent and neutral country, Switzerland offered the BIS less exposure to undue influence from any of the major powers. Within Switzerland, Basel was chosen largely because of its location and excellent railway connections in all 
directions. This was especially important at a time when most intracontinental travel in Europe was by train" (BIS, 2005).

The BIS' initial capital was fixed at 500 million gold francs, ${ }^{1}$ which served as the BIS currency of record until 2003. This initial capital investment was divided into 200,000 shares and was allocated equally to five key central banks, along with two banking groups. The banks were the Bank of England, the National Bank of Belgium, the Bank of France, the Bank of Italy, and the German Reichsbank. The first of these two banking groups served as a proxy for the Bank of Japan, while the second group was created by and represented three United States banks: J.P. Morgan, the First National Bank of New York, and the First National Bank of Chicago (Auboin, 1955). Until 1994, despite having two seats on the board reserved for it since the founding of the BIS in 1930, the Federal Reserve did not take a seat as a member of the BIS Board of Governors. The Federal Reserve was prohibited from being a "founding bank" by the US Government. The Federal Reserve was "not allowed to join because the US government thought membership would conflict with its official position on reparations" (Fratianni and Pattison, 1999). The US did not agree with and had not been a party to the reparation's settlement with Germany. As a result, several large and powerful US commercial banks joined in support and collaboration with the BIS. US participation was maintained unofficially through these channels until 1994. On September 13, 1994, the Federal Reserve formally joined the BIS' Board of Directors. In April 2003 the BIS changed from gold francs to having its financial statements denominated in Special Drawing Rights. ${ }^{2}$

Although the BIS was established in Basel, Switzerland, the BIS operates independently of Swiss banking and corporate laws. The BIS is not subject to Swiss government interference and taxes, in both times of war and peace, per The Hague Convention as agreed to at the Convention conference on January 20, 1930. The Hague Convention decrees that the BIS is an international organization and is governed by international law, along with the commensurate privileges and immunities afforded such international institutions. This status was viewed as necessary to the BIS performance of its charter. The BIS' legal status in Switzerland was further clarified in a formalized 1987 agreement between the Swiss Federal Council and the BIS. Specifically, the BIS demanded and was granted the following similar rights and immunities that many international organizations enjoy (Wood, 2005; BIS, 1987):

- Diplomatic immunity for persons and any material carried by them such as diplomatic pouches.

- Salaries paid to employees and any transactions associated with the BIS are not subject to taxation.

- Any office or building operated by the BIS enjoys embassy-type immunity.

- No oversight or knowledge of BIS operations will be conducted by any government authority.

- The BIS will not be subjected to any immigration restrictions.

- The BIS is free to encrypt any and all of its communications, of any sort.

- "Immunity from arrest or imprisonment and immunity from seizure of their personal baggage, save in flagrant cases of criminal offence."

- Inviolability of all papers and documents.

- Immunity from jurisdiction, even after their mission has been accomplished, for acts carried out in the discharge of their duties, including words spoken and writings.

- Exemption for themselves, their spouses and children from any immigration restrictions, from any formalities concerning the registration of aliens, and from any obligations relating to national service in Switzerland.

- The right to use codes in official communications or to receive or send documents or correspondence by means of couriers or diplomatic bags.

As the Great Depression progressed in the early 1930's, the US economy slid into financial abyss. Through contagion the global economy quickly followed the US lead into the chasm of depression. Germany, which still had not recovered from the effects of WWI, was especially hard hit. This led a cessation of reparations payments as Germany no longer had the financial wherewithal to make them. This precipitated an evolution in the original role of BIS beyond its original charter.

\footnotetext{
${ }^{1}$ The gold franc was originally based on the Franc Germinal, a currency unit created by the Banque de France in 1803 . The Franc Germinal was maintained as the basis for the gold franc by the nations in the Latin Monetary Union until the union formally ended in 1927. After that the value of one gold franc was maintained at 0.290322 ounces of fine gold.

${ }^{2}$ This is discussed in more detail later in this paper.
} 
The inability of Germany to continue reparation payments, in concert with the global disarray resulting from the Great Depression, put the future of the BIS' continued existence into question. In fact, given the original stated purpose of the BIS to manage Germany's WWI reparations payments "the BIS would have disintegrated in 1932 when the Lausanne Agreement brought an end to war reparations" (Fratianni \& Pattison, 1999). However, Article 3 in the BIS' statue stated that the function of overseeing reparations was secondary to providing a forum for central bank cooperation. Some forward-thinking BIS founder had foreseen the eventual cessation of reparations payments and provided other and seemingly more defendable justification for the BIS' continued existence. At this point the BIS began to take on the form of a central bank for central banks.

\section{IMPACT OF WORLD WAR II}

During World War II (WWII), the BIS suspended many of their operations, however, active collaboration and relations with its members continued. During the war, accusations arose that the BIS was essentially laundering money for Nazi Germany and the Reichsbank, who had stolen much of it from the occupied territories. These accusations only fueled US and British suspicions that the BIS had a special alliance with Berlin and Reichsbank during the war. It was later discovered that these accusations weren't entirely baseless accounts and were at least partly true. Eventually, "five BIS directors, including Hjalmar Schacht, were charged with war crimes" (Lebor, 2013b), based on their roles and actions with Nazi Germany.

An interesting fact is that during WWII the BIS' board members, along with other representatives, from both the Axis and Allied combatants continued to work side-by-side doing the work of the BIS. This presented a unique opportunity for the warring nations. Direct and official communications between the Axis and Allied sides had ceased with the onset of war, yet back channels for communicating between the warring sides were deemed advantageous, if not necessary. The fact that key members of both the Axis and Allied powers were working side-by-side at the BIS provided a unique opportunity for these unofficial back-channel communications. It also presented an occasion for German bankers and industrialists, who had come to the conclusion that the war was lost for Germany long before the official German surrender, to begin working with the eventual Allied occupiers of Germany. These German bankers and industrialists wanted to mitigate similar post-war German economic maladies as what Germany had experienced after WWI. It was in both sides' interest to expedite Germany's economic recovery after Germany's anticipated surrender. Reportedly, through these indirect and unofficial channels, German industrialists had some influence on the target designations of the US and British strategic bombing campaigns in Germany during the war (Lebor, 2013b).

Approximately 10 months prior to the surrender of Germany, and the cessation of WWII in the European theater, ${ }^{3}$ delegates from several Allied nations met in Bretton Woods, New Hampshire, to negotiate and craft a new post-war international monetary system. The conference was held from July 1 to 22, 1944 and was officially designated as the United Nations Monetary and Financial Conference, although it later became more commonly referred to as the Bretton Woods Conference. Led by the United States, the United Kingdom, and Canada, the Bretton Woods Conference established two institutions with the hopes of replacing BIS; the International Monetary Fund (IMF) and the International Bank for Reconstruction and Development. "The US tried to use the IMF's creation as a reason to get rid of the BIS" (Suter, 2004). The US thought that there was too much German influence in the BIS before, during, and after the war, and it appeared to be mostly a European club effectively restricted to regional membership. Additionally, the US argued that the financial scope of the BIS was too narrow; therefore, questioned its real-world usefulness. Hence, due to the US' unparalleled clout in the immediate post-WWII era, for the second time in its short history the BIS was on the brink of extinction.

The Bretton Woods Conference implemented a new global currency exchange system, "where all currencies were linked to the US dollar and in exchange, the US agreed to fix the price of gold at \$35/ounce" (Bowers, 2015). This change in the exchange system essentially eliminated much of the international need for the BIS's currency manipulation services and, hence its raison d'etre. Moreover, the argument was that since IMF would now be the center of the new global financial order, the BIS was redundant.

\footnotetext{
${ }^{3}$ World War II ended in the European theater on May 7, 1945 with the surrender of Germany. The war continued in the Pacific Theater until September 2, 1945 with the surrender of Japan.

${ }^{4}$ The International Bank for Reconstruction and Development is the first and foremost institution of what is known today as the World Bank.
} 
The primary advocate of dissolving the BIS was US President Franklin D. Roosevelt. However, President Roosevelt died in April 1945 and, with him, the strongest advocacy of liquidating the BIS also died.

In reality, the IMF could not replace BIS. The BIS had evolved by this time to become much more than just an international financial clearing house; the BIS was now a supranational organization for developing and putting into practice new global monetary strategies. Instead of being dissolved, the BIS garnered even more authority, especially in coordinating financial transactions intended to help maintain international financial market stability (Wood, 2005). The BIS reinvented itself as the primary clearing house for European currencies and as the preferred rendezvous of central bankers. The BIS was even instrumental in helping to shore up the US Dollar when the US currency came under international attack in the 1960's. The BIS accomplished this through massive swaps of money and gold. In a reflection on the irony of the situation, the then-president of the BIS observed, "the United States, which had wanted to kill the BIS, suddenly finds it indispensable."

\section{BRIDGING ITS CONTRIBUTIONS}

In the immediate post WWII era, the BIS emerged as a major international institution in increasing the efficiency of the international banking system. The BIS established itself as a world leader in ensuring the stability of the global financial system. The BIS' many financial-system endeavors over the next several decades would further solidify its role in the global economy. "Fundamentally, the most important belief of the BIS' inner club is its conviction that when the bell tolls for any central bank, it tolls for them all" (Wood, 2005).

A prime example of how collaboration is key among central banks is the Mexican debt crisis of 1982. Mexico's debt problem began to snowball after continually borrowing fed funds from the interbank network in New York to cover its interest on $\$ 80$ billion in loans. Mexico finally advised the Federal Reserve that it could no longer cover the loan, and that default and the exhaustion of the Mexico's reserves were eminent. As a result, the BIS provided Mexico a bridge loan of $\$ 1.85$ billion to assist in getting Mexico out of the interbank market (RaboResearch, 2013). While public accounts of the loan would show that the funds came directly from BIS, "almost all of the funds came from central bank members, including the Fed, Bundesbank, Swiss National Bank, Bank of England, Bank of Italy, and Bank of Japan. The BIS undertook no risk in this rescue operation but rather coordinated this assistance among central banks" (Wood, 2005). This collaboration among central banks helped prevent a growing crisis from spreading to other regions. The Mexican crisis is only one example how BIS has repeatedly played a role as a crisis manager to help promote international financial stability.

In addition to promoting cooperation among central banks, the BIS has also made great efforts to promote monetary and financial stability through various committees that develop and recommend suggested procedures and regulations. While there is a long list of BIS committees, the three permanent and more influential are the Basel Committee on Bank Supervision (BCBS), the Committee on Payment and Settlement Systems, and the Committee on the Global Financial System. The oldest and most active of the committees is the BCBS. Many observers believe that the BCBS "is the most likely of the existing BIS bodies to metamorphose into a supreme international bank regulator" (Suter, 2004). However, it is important to note that the BIS nor the BCBS possess any formal authority or legal force to implement any of their suggestions, but in the real-world workings of international finance, it is usually in a bank's best interest to adopt or mimic the practices suggested by the BIS through the BCBS.

The creation of BCBS was based on the failure of Herstatt Bank, which ultimately caused a chain of defaults in the foreign exchange markets (Forex). The Herstatt Bank was a major German bank that went bankrupt in 1974 because of mismanagement of its foreign exchange accounts and subsequent default. German banking regulators forced it into liquidation. This event lead to the creation of the BCBS to help preclude a repeat of this event somewhere else in the world.

In collaboration with the $\mathrm{G} 10$ countries, ${ }^{5}$ the $\mathrm{BCBS}$ was charged with implementing a committee that was responsible for setting standards for bank regulation and establishing a forum for the discussion of bank supervisory matters. The BCBS operates under two principles; first, all international banking establishments are subject to regulation and

\footnotetext{
${ }^{5}$ The G10 countries are a group of countries that agreed to provide the International Monetary Fund (IMF) with additional funds as necessary to increase the IMF's ability to lend funds. These countries signed the General Agreements to Borrow (GAB) agreement to take part in this endeavor. The G10 countries in alphabetical order are Belgium, Canada, France, Germany, Italy, Japan, the Netherlands, Sweden, the United Kingdom, and the United States.
} 
second, supervision of these institutions should be adequate to ensure compliance with those regulations. While the BIS performs secretariat functions for the BCBS, the BCBS remains technically separate from the BIS. Moreover, the BCBS relies on the G10-country endorsements for specific initiatives to pursue. The BCBS has produced two important documents and guidelines for banking regulation; first the Basel Concordat and second, the distinguished and highly regarded Basel Capital Accord. The Basel Concordat is the "backbone of international bank regulation and sets out certain principles, which the Committee believes should govern the supervision of banks' foreign establishments by parent and host authorities" (Lebor, 2013b). Similarly, The Basel Capital Accord was originally released in 1988, following the Mexico financial crisis previously discussed. The purpose of the Basel Capital Accord is to bring about international consensus on supervisory regulations addressing the capital adequacy of international banks. The Basel Capital Accord has gone through several amendments and additions over the years (BIS, 1999).

In 1995, the BCBS issued a document titled the "Core Principles of Effective Banking Supervision." The document defines twenty-five key areas of banking supervision and outlines the essential ingredients of a regulatory banking structure that are intended to stimulate confidence in the international banking market. According to the BCBS, they "intended the Core Principles to be applied in all countries... and is the most important global standard for prudential regulation and supervision" (BIS, 1997). The committees and the documents the BIS create have been instrumental in the sustaining a collaborative central bank network and in ensuring a stable international banking system.

\section{BIS CREATED INSTITUTIONS}

In addition to several key committees that are associated with the BIS, the bank has also established the Financial Stability Board (FSB) and the Financial Stability Institute (FSI). The FSB was previously known as the Financial Stability Forum (FSF). The FSF was established in 1999, while the FSB replaced it in 2009. Both the FSF and later FSB were created to promote improved information exchange and cooperation between international banks to promote greater international financial stability. The FSB today includes all G20 countries, ${ }^{6}$ Spain, and the European Commission. ${ }^{7}$ The FSB will "monitor potential risks in the economy, especially those involving the biggest firms, and will conduct early warning exercises along with periodic review to spot potential trouble" (Moya, 2009). The FSB encourages financial institutions to establish and maintain contingency plans to address insolvency if the firms collapse. Similarly, the Financial Stability Institute (FSI) was also created in 1999 by the BIS and BCBS. According to BIS, the FSI's objectives include (BIS, 2018d):

- Promote sound supervisory standards and practices globally and support full implementation of these standards in all countries.

- Keep supervisors updated with the latest information on market products, practices, and techniques.

- Provide a venue for policy discussion and sharing of supervisory practices and experiences.

- Promote cross-sectoral and cross-border supervisory contacts and cooperation (BIS).

In addition to the FSB and FSI, the BIS has also been instrumental using the support and secretariat functions of several other committees, such as the BCBS, in promoting global financial stability.

\section{BIS UNIT OF ACCOUNT}

As previously discussed, at its inception in 1930, the BIS' unit of account was the gold franc. The "unit of account" is the currency unit the BIS' financial statements are denominated in. On April 1, 2003 the BIS replaced the gold franc with Special Drawing Rights (SDR), a foreign-exchange reserve asset deriving its value from a "basket of currencies" defined and maintained by the IMF. The SDR was established in 1969. The SDR was implemented under the Bretton Woods Exchange System as an ideal reserve currency because of concerns about the US Dollar in that role, especially due to gold being held to a fixed price denominated in US Dollars. Specifically, the US Dollar is subject to the national political influences of Washington, DC, and, as a result, its market value in the world can vary significantly as political ideologies can vary greatly with each election cycle. Many in the world find this unacceptable; hence, the international

\footnotetext{
${ }^{6}$ The G20 includes government officials and central bank governors from the following nations, listed alphabetically: Argentina, Australia, Brazil, Canada, China, France, Germany, India, Indonesia, Italy, Japan, Mexico, the Republic of Korea, the Russian Federation, Saudi Arabia, South Africa, Turkey, the United Kingdom, the United States, and the European Union (the European Union is treated as a separate nation apart from its member nations).

${ }^{7}$ The European Commission is an institution under the European Union (EU). It is the executive cabinet of the EU.
} 
community decided to address this matter by creating a new international reserve asset under a politically-nonaligned financial institution, the IMF. The SDR is a basket of the predominant world currencies, weighted by their assessed relative importance in the global economy. The current basket, ${ }^{8}$ per the IMF, is made up of the US Dollar (41.73percent), Euro (30.93-percent), Chinese Renminbi (10.92-percent), Japanese Yen (8.33-percent), and British Pound Sterling (8.09-percent) (IMF, 2018). The specific currency composition, and associated weightings, of the SDR is reviewed every five years. In general, SDR's are only used by nations. While SDR's may be used as a baseline currency value for pricing purposes in business contracts, SDR's are not held by businesses and business is not conducted using them.

According to BIS' 2003-2004 annual report: 9 “The Bank's use of the gold franc as its unit of account had been regarded as non-transparent and inconsistent with current standards of accounting best practice. For these reasons, and in order to assist in managing the Bank's operations and economic capital more efficiently, it was decided to adopt the SDR as the Bank's new unit of account. The SDR is the unit of account of the IMF and is also used in private contracts and international treaties and as the unit of account of other international organizations" (BIS, 2004).

\section{BIS TODAY}

Today, the BIS is the oldest international bank in the world. The BIS has evolved to become an essential element in the global financial system and is universally regraded as the central bank for central banks. From its inception in 1930, the BIS has shown its ability to adapt and evolve with the changing international markets. While the BIS held a rather narrow scope at its inception and was considered more of a European club in those early years, it has evolved to provide a mutually beneficial forum for the world's central banks to support and foster international monetary stability. The BIS was instrumental in establishing "four of the most important international committees dealing with global banking: the Basel Committee on Banking Supervision, the Committee on the Global Financial System, the Committee on Payment and Settlement Systems, and the Irving Fisher Committee" (Lebor, 2013b). In addition to serving a secretariat role to the prominent committees, the BIS currently maintains one of the world's largest caches of gold reserves. Further, "the countries represented through the BIS and the Global Economy Meetings together account for around four-fifths of global gross domestic product, which is...most of the produced wealth of the world" (Lebor, 2013a) $\cdot{ }^{10}$ Over the decades, the BIS has grown from a regionally-oriented organization to a truly global and powerful banking institution. Approximately 60 central banks are members of the BIS (BIS, 2018e). ${ }^{11}$ And, while not all banks are official members of BIS, almost all conduct business with BIS. Through its ever-expanding role, the BIS facilitates international financial order; hence, remains a relevant and pivotal financial institution.

\section{DISCUSSION}

The Bank of International Settlements (BIS) is considered by many to be the bankers' bank; the central bank for central banks. It is an institution that is not well known publicly, however, it has nonetheless been an important institution in the global arena of money, power, and behind-the-scenes global influence. While the BIS has never been a secret organization, knowledge of their existence is very limited. Indeed, even President Bill Clinton, who spent two years campaigning about economics during the 1992 US presidential election, seemed unaware of BIS, let alone the rather limited powers he would have over the Federal Reserve and the financial markets (Suter, 2004). The BIS has never advertised its existence and its buildings in Basel, Switzerland have always been nondescript and quite ordinary looking. Still, for an international bank, with such a detailed website filled with data, annual reports, statistics, and even their own Twitter account, the lack of general knowledge of what BIS is and what it does it is truly amazing. With the bandwagons of anti-bankers and never-capitalists that relentlessly protest the pursuit of profits, it is almost surreal that an international financial institution of the BIS' power and influence, that has existed since 1930, has been subject to little, if any, criticism from the general population. This is especially true when one considers just how much power and influence the BIS ultimately has over everyone's lives. The BIS seems to have truly become the central bank for central banks and, hence, is arguably the world's single most important financial institution.

\footnotetext{
${ }^{8}$ As of 2016, the last currency review.

${ }^{9}$ Because this change occurred in 2003, the 2003-2004 BIS Annual Report is the report that discusses the change.

10 The Global Economy Meetings constitute a forum for discussions between the world's central banks governors during the BIS bi-monthly meeting. There are two primary objectives of these forums: (1) monitor and assess developments in the world economy and the global financial system, and (2) provide guidance to, and receive reports from the Committee on the Global Financial System (CGFS) and the Committee on Payments and Market Infrastructures (CPMI).

${ }^{11} \mathrm{~A}$ list of the member central banks is available at https://www.bis.org/about/member_cb.htm?m=1\%7C2\%7C601.
} 
The following questions are posed as open-ended points of discussion. That is, there are no correct or incorrect answers, per se. The intent is to promote scholarly argument of the pros and cons of the existence of such a powerful international financial institution, and the impact that institution has on national and international financial systems. Ideally this paper in concert with the follow-on discussion will promote greater in-depth student research into this powerfully influential financial institution, into central banking in general, and from that a better understanding of the global financial system.

- Why is that that a financial institution that has so much influence over the global financial system; hence, over the lives of most people is so unknown? This is true even among financial and economic professionals. While the BIS has never advertised its existence and has sought a low profile, the bank is nonetheless not a secret institution.

- Does the BIS really provide useful services to the world's nations and to the world as a whole? If so, can't the various nations of the world address these matters themselves adequately or is a global organization such as the BIS really needed?

- Does the BIS represent an unelected and far-too-powerful entity that could, under less-than-benevolent leadership, wield far too much power over the nations of the world?

- Does the BIS and its SDR unit of account indicate a migration of the world's currencies to single currency and eventually a global economic union on the model of the Euro and the Eurozone? If so, is that a stepping stone towards one-world government?

- Should the BIS be maintained as is, changed to something else, or dissolved?

\section{AUTHOR BIOGRAPHIES}

Michael P. Hughes is a professor of finance at Francis Marion University in Florence, South Carolina. Dr. Hughes holds a Ph.D. in finance, an MBA, and a BSET in operations. Dr. Hughes' research interests lie in financial markets, market microstructure, financial econometrics, fixed income securities, central banking, and government finance, to include defense finance. Prior to his being an academic, Dr. Hughes served for over 21 years in the US Air Force, the first seven of which were with F-4 and F-15 fighter aircraft. The remaining 14 years were in the nuclear treaty monitoring and associated activities.

Chris Palke is a Financial Institution Specialist at the Federal Deposit Insurance Corporation (FDIC). Mr. Palke is a graduate of Francis Marion University and holds a BBA in finance. He is currently pursuing Financial Risk Manager (FRM) and Chartered Financial Analyst (CFA) credentials. Mr. Palke served four years with the United States Marine Corps with a specialization in infantry and combat operations. Following his tour of duty in the Marines, Mr. Palke served as a general manager with a logistics firm for eight years, specializing in financial and operational management.

\section{REFERENCES}

Auboin, R. (1955). The Bank for International Settlements. Department of Economics and Sociology: Princeton University: 3. Retrieved from http://www.worldcat.org/title/bank-for-international-settlements-1930-1955/oclc/950241750.

BIS (1987). Agreement between the Swiss Federal Council and the Bank for International Settlements to determine the bank's legal status in Switzerland. Retrieved from https://www.bis.org/about/headquart-en.pdf.

--- (1997). Core principles for effective banking supervision. Retrieved from https://www.bis.org/publ/bcbs30a.pdf.

--- (1999). Capital requirements and bank behaviour: The impact of the Basle Accord. Retrieved from https://www.bis.org/publ/bcbs_wp01.pdf.

--- (2004). 2003-2004 annual report. Retrieved from https://www.bis.org/publ/ arpdf/ar2004e.pdf.

--- (2005). This is the biz. Retrieved from https://www.bis.org/about/thisisthebiz.pdf.

--- (2018a). BIS overview. Retrieved from https://www.bis.org/about/index.htm?m=1\%7C1.

--- (2018b). Products and services. Retrieved from https://www.bis.org/banking/ finserv.htm.

--- (2018c). Board of directors. Retrieved from https://www.bis.org/about/ board.htm?m=1\%7C2\%7C2.

--- (2018d). Financial Stability Institute. Retrieved from https://www.bis.org/fsi/index.htm?m=1\%7C17\%7C629

--- (2018e). "BIS Member Central Banks." Retrieved from https://www.bis.org/about/ member_cb.htm?m=1\%7C2\%7C601.

Bowers, D. (2015). One bank to rule them all: The Bank for International Settlements. Hampton Institute. Retrieved from https://www.activistpost.com/ 2015/10/one-bank-to-rule-them-all-the-bank-for-international-settlements.html

Felsenfeld, C., \& Bilali, G. (2004). The role of The Bank of International Settlements in the world financial system. Journal of International Law, 25(3), 945-1045. University of Pennsylvannia, .

Fratianni, Michele, \& John Pattison (1999). An assessment of The Bank for International Settlements. International Financial Advisory Commission: 9. Retrieved from https://papers.ssrn.com/sol3/papers.cfm?abstract_id=956482.

Copyright by author(s); $\underline{\text { CC-BY }}$ 
IMF (2018). Special Drawing Right (SDR). Retrieved from https://www.imf.org/en/About/Factsheets/Sheets/2016/08/01/14/51/Special-Drawing-Right-SDR.

Lebor, A. (2013a). Meet the secretaive group that runs the world. Retrieved from https://www.zerohedge.com/news/2015-0411 /meet-secretive-group-runs-world

--- (2013b). Tower of Basel. Public Affairs, Perseus Books Group. New York, NY.

Moya, E. (2009). Financial stability board: How it will work. The Guardian. Retrieved from https://www.theguardian.com/world/2009/apr/04/financial-stability-board-g20.

RaboResearch (2013). The Mexican 1982 Debt Crisis. Retrieved from https:/economics.rabobank.com/publications/2013/september/the-mexican-1982-debt-crisis/.

Suter, K. (2004). The Banker' Bankers' Bank: The Bank of International Settlements. Questia. Retrieved from https://www.questia.com/magazine/1G1-120722350/the-bankers-bankers-bank-the-bank-of-international.

Wood, P. (2005). Global banking: The Bank for International Settlements. NewsWithViews. Retrieved from http://www.newswithviews.com/Wood/patrick4.htm. 